УДК 330.122

DOI: https://doi.org/10.37320/2415-3583/10.20

Приймак B.I.

доктор економічних наук, професор,

Львівський національний університет імені Івана Франка ORCID: https://orcid.org/0000-0003-0244-8661

Голубник О.P.

кандидат економічних наук, доцент, Львівський начіональний університет імені Івана Франка ORCID: https://orcid.org/0000-0003-1211-4614

\title{
ОЦІНЮВАННЯ ВІЛЬНОГО ЧАСУ СУСПІЛЬСТВА В СИСТЕМІ ФОРМУВАННЯ ДОБРОБУТУ ДОМОГОСПОДАРСТВ
}

\begin{abstract}
Проаналізовано основні підходи до оиінювання економічного добробуту населення. Обтрунтовано необхідність під час вимірювання економічного добробуту суспільства враховувати такий його компонент, як вільний час. Охарактеризовано напрями використання вільного часу у суспільстві. Виконано структурний поділ вільного часу на дві частини, а саме дозвілля та «більш піднесену діяльність». Виконано порівняльний аналіз оплачуваної роботи, неоплачуваної роботи та вільного часу у різних країнах. Встановлено, щчо в Украӥні величина показника «частка відпраџьованого часу особи для добового фонду часу» є набагато меншою від значення иьього показника для інших краӥн. Відмінність величини розглянутого показника для Украӥни та інших краӥн пояснюється великими обсягами тіньової економіки і тіньової зайнятості в нашій країні. Розраховано середній час за добу, який витрачається на оплачувану пращчю однією особою у віці 15-70 років та працеездатному віціі в Украӥні у $2010-2017$ рр. без урахування $і$ з урахуванням тіньової зайнятості.
\end{abstract}

Ключові слова: добробут, економічний добробут домашніх господарств, вільний час, дозвілля, оплачувана робота, неоплачувана робота.

Постановка проблеми. Структурна трансформація національної економічної системи змінюе орієнтири та пріоритети соціально-економічного розвитку суспільства. Соціальний розвиток у контексті цих перетворень передбачає передусім забезпечення зростання рівня життя населення. Основою розвитку, вдосконалення і повноцінного життя людини є кількісне зростання та якісне поліпшення добробуту населення.

Сьогодні категорія «добробут населення» охоплює не тільки матеріальні параметри функціонування домогосподарств, а й можливості для забезпечення довгого і здорового життя та продуктивної професійної діяльності. Добробут розглядається в широкому сенсі як комплексна соціально-економічна категорія, системне утворення, яке характеризує все різноманіття проявів людської життєдіяльності.

Оскільки в сучасному світі час як ресурс $\epsilon$ одним із найцінніших разом зі знаннями та інформацією, все більшого значення набуває питання збільшення та ефективного використання вільного часу членами домогосподарств. Особливість цього питання полягає ще й у тому, що з формуванням інформаційної економіки та інформаційного суспільства відбулися суттєві зміни у способі життя громадян як нашої, так і інших країн, змінилися пропорції у розподілі часу між роботою і відпочинком працівників [1].

Аналіз останніх досліджень і публікацій. Проблеми аналізу та оцінювання добробуту населення були об'єктом дослідження багатьох зарубіжних та українських науковців, серед яких можна виділити А. Аткінсона, Г. Далі, Т. Кір'ян, Дж. Кобба, С. Колма, Е. Лібанову, В. Мандибуру, В. Нордгауза, А. Пігу, С. Пирожкова, А. Ревенка, П. Самуельсона, А. Сена, Дж. Тобіна та ін. Так, А. Пігу для оцінювання введеного ним показника економічного добробуту запропонував використовувати валовий внутрішній продукт (ВВП) на душу населення. Через суттєві недоліки, які має такий підхід до вимірювання економічного добробуту, В. Нордгауз і Дж. Тобін увели в науковий обіг інший показник, який П. Самуельсон назвав чистим економічним добробутом (ЧЕД) [2, с. 151]. Для розрахунку ЧЕД від величини ВВП віднімають і до неї додають вартісну оцінку відповідно негативних і позитивних чинників. Серед чинників, які збільшують величину ЧЕД, ці науковці називають, зокрема, грошову оцінку вільного часу [1].

Різні аспекти вільного часу досліджували В. Бочелюк, Р. Вінярський, А. Жепка, Г. Зборовський, Б. Грушин, О. Кендюхов, Г. Крапівіна, В. Лара, Є. Приступа, К. Ягельська та ін. Однак в оприлюднених публікаціях учених відсутні результати наукових досліджень, які б стосувалися проблеми оцінювання вільного часу населення певного регіону чи якоїсь країни. 3 огляду на це, дослідження вільного часу суспільства як складника його ЧЕД, визначення підходів до вимірювання цього часу $\epsilon$ актуальною науковою проблемою. 
Мета статті полягає у теоретичному аналізі сутності вільного часу населення як одного зі складників чистого економічного добробуту домогосподарств регіону чи країни у цілому та розробленні можливих підходів до оцінювання його обсягів.

Виклад основного матеріалу. Протягом останніх десятиліть основним економічним індикатором вимірювання добробуту населення є ВВП на душу населення. Цей показник активно використовується для розроблення економічної і соціальної політики, а також для порівняння рівня життя в різних країнах. Однак останнім часом усе більше уваги приділяється обмеженості застосування цього інструмента для відображення сукупного добробуту населення. Як критерій аналізу зміни добробуту та рівня життя населення, який містить як суб'єктивні, так і об'єктивні індикатори, пропонують використовувати показник вільного часу та якості його використання.

Час окремої людини, членів якогось домогосподарства чи цілого суспільства має певну соціальну цінність. Його завжди можна розділити на робочий і позаробочий, який кожна особа витрачає на певні види діяльності, що не пов’ язані безпосередньо $з$ іiі трудовою зайнятістю. Кожний зі складників часу має певне призначення, відповідний соціально-культурний зміст, а також свої функції [1].

Опрацювання літературних джерел із розглянутої проблематики і викладеного вище дало змогу виділити напрями, за якими вільний час використовується у суспільстві (рис. 1).

Щодо напрямів використання вільного часу українцями, то про них можна судити з результатів соціологічного опитування населення компанією Nielsen (Nielsen Global Survey Generational Lifestyles), яке було проведено в період iз 23 лютого по 13 березня 2015 р. Опитування показало, що за популярністю у видах дозвілля в українців лідирують сімейні цінності і соціальні мережі. Проводити час із друзями та родиною вважають за краще 35\% респондентів. Соціальні мережі становлять дозвілля також третини українців. Результати опитування показали, що на другий план серед видів проведення вільного часу відійшло телебачення (24\%), поступаючись місцем читанню 3 показником 27\%. Далі серед пріоритетних видів дозвілля українці назвали кулінарію (20\%), музику (17\%) та онлайн-ігри (15\%). На відміну від українців майже половина мешканців деяких європейських країн під час проведення свого вільного часу замість спілкування з друзями і родичами, читання чи приготування їжі перевагу надають телебаченню. Так, у Румунії перед телевізором проводять час $45 \%$ опитаних, у Великобританії-44\%, в Італії - 43\% [3].

Як було сказано вище, підвищення рівня розвитку економіки і суспільства веде до поліпшення добробуту населення. Зростає заробітна плата,

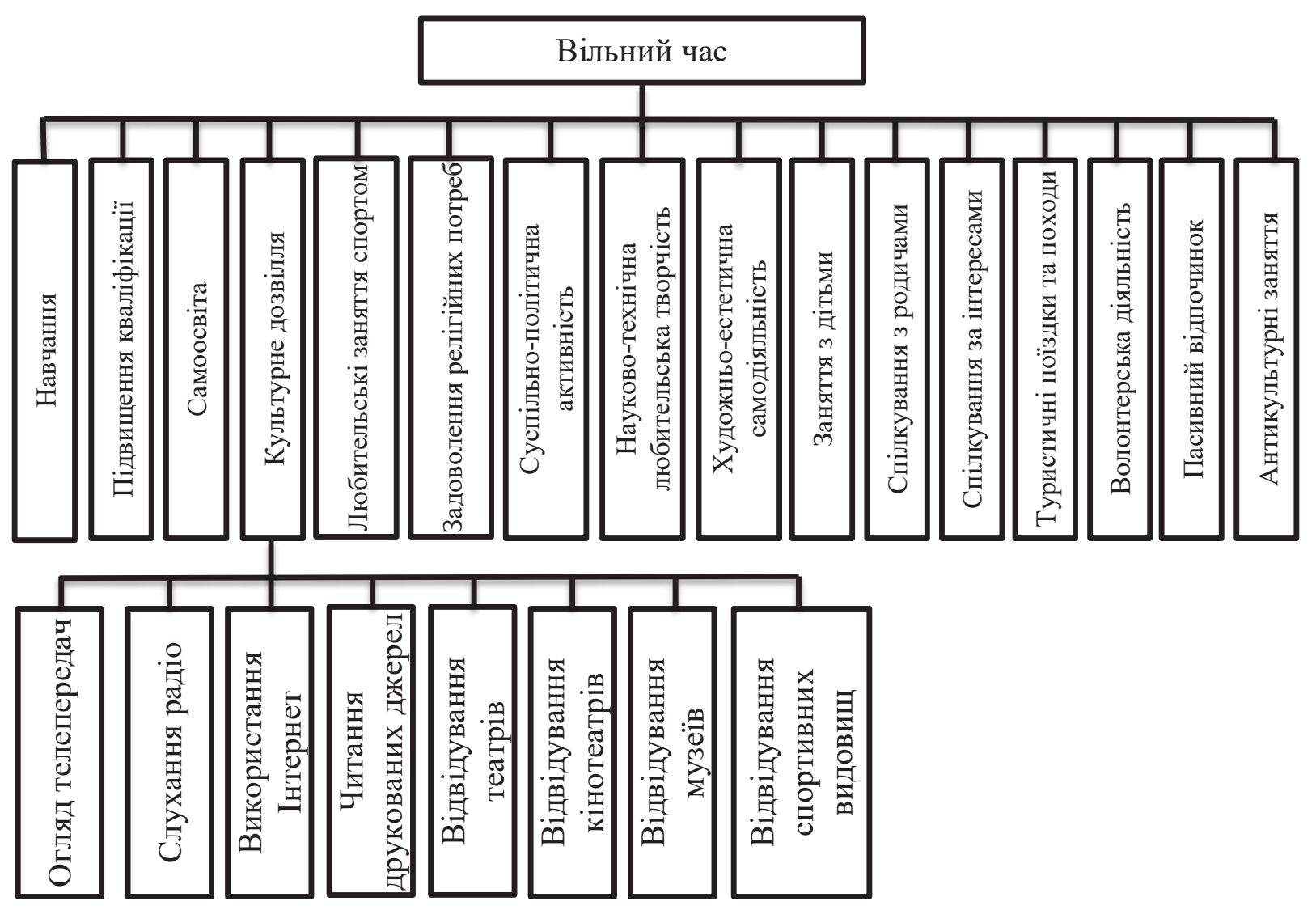

Рис. 1. Напрями використання вільного часу у суспільстві 
поліпшуються умови праці, збільшуються можливості для проведення дозвілля тощо. 3'являється можливість за менший час заробити більше грошей, чим користуються деякі працівники для скорочення свого робочого і збільшення вільного часу. Такий процес є позитивним явищем, однак він має певні негативні боки. Зокрема, великі обсяги вільного часу у безробітного не приносять йому задоволення $\mathrm{i}$ не збільшують рівень його добробуту. Замість відпочинку час його незайнятості веде до дискомфорту і незадоволення, адже фактично суспільство відмовилося від цього часу, і нічого позитивного людині він не несе, а тільки погіршує іiї життя. Інший приклад: людина добровільно відмовляється від будь-якої трудової діяльності, навчання чи іншого заняття та веде антисуспільний спосіб життя. Вільний час такого індивіда відіграє не позитивну, а негативну роль.

Під час дослідження вільного часу потрібно розрізняти дві його найважливіші частини. Перша 3 них - це дозвілля, а друга - «більш піднесена діяльність». Деякою мірою ці частини близькі одна до одної, але не рівнозначні. Хоча іноді, найчастіше в побуті, перше із цих понять ототожнюють із вільним часом, але це неправильно. Вільний час у певних випадках відіграє роль дозвілля, але не завжди. Під час дозвілля людина відновлює витрачені на роботі психофізичні та духовні сили, а під час більш піднесеної діяльності - розвивається й удосконалюється як особистість, хоча розвиток особистості певною мірою відбувається і в час дозвілля.

С. Струмилін, досліджуючи проблеми вільного часу, також поділив його на дві частини. Перша частина - час, котрий затрачується на необхідну суспільну, творчу й іншу діяльність: підвищення кваліфікації, навчання, заняття 3 дітьми, суспільні обов'язки, художня самодіяльність. Друга частина - це власне дозвілля: хобі, споживання духовних благ, фізкультура, зустріч із родиною, прогулянки, туризм, читання газет, книжок, культурний відпочинок (кіно, музей, театр, інші розваги, домашні ігри, прийом гостей), бездіяльний, «пасивний» відпочинок та ін. [4].

Таким чином, дозвілля - це та частина вільного часу, яка використовується людиною для відпочинку і розваг, споживання культури та інших занять, що дадуть їй змогу відновити свої фізичні і психічні сили.

До дозвілля можна віднести: індивідуальне споживання культури (читання книг, журналів, газет, прослуховування радіо, перегляд телепередач i т.п.); публічно-видовищне споживання культури (відвідування театрів, кіно, концертів, музеїв, спортивних видовищ і т. ін.); спілкування (із членами родини, родичами, сусідами, друзями тощо); фізичні заняття (ранкова і вечірня гімнастика, водні процедури і т. ін.); розваги й ігри, що знімають розумове і фізичне напруження, створюють добрий настрій; пасивний відпочинок (прогулянки без певної мети, спокій, зміна напруженості врівноваженістю й ін.); заняття, які можна вважати явищами антикультури (зловживання алкоголем, хуліганство, злочинність, наркоманія, азартні ігри, безцільне проведення часу як розпущений спосіб відпочинку). Заняття більш піднесеної діяльності можна згрупувати в такий спосіб: навчання без відриву від виробництва; підвищення кваліфікації; самоосвіта; суспільно-політична діяльність; участь у вихованні дітей; творча діяльність і аматорські заняття; спортивні заняття й туризм [5].

Структурний поділ вільного часу на вказані дві частини є певним чином умовний. Ці частини деякими заняттями перекривають одна одну, хоча для оцінювання обсягів вільного часу це не має надто суттєвого значення. Головне, що заняття кожної із цих частин впливають на особистість, розвивають та поліпшують іiі фізичне і психічне здоров'я.

Розглянутий поділ вільного часу на дві структурні частини не має суттєвого значення для розроблення можливих підходів до оцінювання обсягів цього часу. Хоча, як показують дослідження науковців, жоден із таких підходів не дасть точної відповіді на поставлене запитання.

Одним із таких підходів може бути соціологічне обстеження населення. На основі отриманих результатів такого обстеження можна зробити висновок про середню тривалість дозвілля і більш піднесеної діяльності. Однак соціологічне обстеження населення потребує часу і фінансових витрат, тому не завжди є практично виправданим.

Можна шукати інші підходи до виконання поставленого завдання. Наприклад, оцінити час, який людина витрачає на всі інші потреби протягом доби. Тоді час, який залишиться, буде вільним часом даної особи. Спробуємо піти таким шляхом. Хоча й тут без результатів соціологічних обстежень населення також не обійтися. Однак тут можна використати деякі результати тих обстежень, які і так регулярно проводяться в Україні, а також у деяких інших країнах світу.

Для того щоб реалізувати цей підхід, потрібно розрахувати тривалість часу, який людина витрачає на виконання оплачуваної роботи, сон, особисту гігієну, працю на благо домогосподарства та ін. Тобто треба оцінити, скільки часу в середньому протягом доби у людини займають усі іiі діï, крім відпочинку і розвитку та вдосконалення їі як особистості.

Для визначення часу, який кожна людина у віці 15-70 років чи працездатному віці витрачає на оплачувану роботу, скористаємося офіційними даними, які опубліковані Державною службою статистики України [6] у 2011-2018 pр. (табл. 1).

Для цього потрібна інформація про економічно активне і неактивне населення у 2010-2017 рр., чисельність зайнятих, скільки відпрацьовано годин 
Таблиця 1

Тривалість робочого часу для осіб у віці 15-70 років та працездатному віці в Україні у 2010-2017 pp.

\begin{tabular}{|l|c|c|c|c|c|c|c|c|}
\hline \multicolumn{1}{|c|}{ Показник\Рік } & $\mathbf{2 0 1 0}$ & $\mathbf{2 0 1 1}$ & $\mathbf{2 0 1 2}$ & $\mathbf{2 0 1 3}$ & $\mathbf{2 0 1 4}$ & $\mathbf{2 0 1 5}$ & $\mathbf{2 0 1 6}$ & $\mathbf{2 0 1 7}$ \\
\hline $\begin{array}{l}\text { Економічно активне населення } \\
\text { у віці 15-70 років, тис осіб }\end{array}$ & 22052 & 22057 & 22012 & 21981 & 19921 & 18098 & 17955 & 17854 \\
\hline $\begin{array}{l}\text { Економічно активне населення } \\
\text { працездатного віку, тис осіб }\end{array}$ & 20221 & 20248 & 20394 & 20478 & 19035 & 17396 & 17304 & 17193 \\
\hline Зайняте населення у віці 15-70 років, тис осіб & 20266 & 20324 & 20354 & 20404 & 18073 & 16443 & 16277 & 16156 \\
\hline Зайняте населення працездатного віку, тис осіб & 18437 & 18516 & 18737 & 18902 & 17188 & 15742 & 15626 & 15496 \\
\hline $\begin{array}{l}\text { Економічно неактивне населення } \\
\text { у віці 15-70 років, тис осіб }\end{array}$ & 12576 & 12266 & 12055 & 11862 & 12023 & 10926 & 10934 & 10945 \\
\hline $\begin{array}{l}\text { Економічно неактивне населення } \\
\text { працездатного віку, тис осіб }\end{array}$ & 7878 & 7602 & 7541 & 7552 & 7618 & 6921 & 7039 & 6846 \\
\hline Населення у віці 15-70 років, тис осіб & 34627 & 34322 & 34067 & 33842 & 31944 & 29023 & 28889 & 28799 \\
\hline Населення працездатного віку, тис осіб & 28099 & 27849 & 27934 & 28030 & 26653 & 24317 & 24343 & 24039 \\
\hline Рівень зайнятості населення у віці 15-70 років, \% & 58,5 & 59,2 & 59,7 & 60,3 & 56,6 & 56,7 & 56,3 & 56,1 \\
\hline Рівень зайнятості населення працездатного віку, \% & 65,6 & 66,5 & 67,1 & 67,4 & 64,5 & 64,7 & 64,2 & 64,4 \\
\hline $\begin{array}{l}\text { Відпрацьовано годин у розрахунку } \\
\text { на одного працівника у році }\end{array}$ & 1638 & 1664 & 1668 & 1664 & 1628 & 1641 & 1684 & 1668 \\
\hline $\begin{array}{l}\text { Частка відпрацьованого часу } \\
\text { на одну особу у віці 15-70 років, \% }\end{array}$ & 10,9 & 11,2 & 11,3 & 11,5 & 10,5 & 10,6 & 10,8 & 10,8 \\
\hline $\begin{array}{l}\text { Частка відпрацьованого часу } \\
\text { на одну особу у працездатному віці, \% }\end{array}$ & 12,3 & 12,6 & 12,7 & 12,2 & 12,0 & 12,1 & 12,3 & 12,3 \\
\hline
\end{tabular}

Джерело: розраховано авторами на основі [6]

у розрахунку на одного працівника у році та тривалість року в годинах. У результаті розрахунків отримуємо частку відпрацьованого часу на одну особу у віці 15-70 років та працездатному віці.

Із табл. 1 видно, що частка відпрацьованого часу особи у віці $15-70$ років у нашій країні становить у середньому від 10,5\% до $11,6 \%$ добового фонду ii часу, а особи працездатного віку - від $12,0 \%$ до $12,7 \%$ часу доби. Відмінність у числах для різних вікових груп пояснюється урахуванням у першій із цих груп пенсіонерів за віком, частка зайнятих яких $є$ відносно меншою порівняно 3 населенням працездатного віку.

Як видно з розрахунків, величина показника «частка відпрацьованого часу особи для добового фонду часу» для обох демографічних груп $\epsilon$ набагато меншою від значення цього показника для інших країн. Наприклад, для Канади у 1998 р. величина цього показника становила $15 \%$ [7, с. 173]. Приблизно таку ж тривалість займає оплачувана робота й у деяких інших країнах (рис. 2) [8]. Як видно із цього рисунка, величина розглянутого показника для різних країн становить приблизно 13-17\%.

Однак для країни з нижчим рівнем економічного розвитку час, який людина витрачає на оплачувану працю, завжди більший за аналогічний час для країни із вищим рівнем економіки, адже в першій із цих країн людина шукає способи збільшення своїх доходів. Одним із таких способів $\epsilon$ збільшення часу оплачуваної праці. У другій з ука- заних країн достатній рівень доходів дає можливість витрачати більше часу не на працю, а на відпочинок, люди не шукають додаткового заробітку.

Відмінність величини розглянутого показника для України й інших країн пояснюється великими обсягами тіньової економіки і тіньової зайнятості в нашій країні. Якщо припустити, що відношення часу тіньової зайнятості до офіційної таке ж, як відношення обсягів тіньової економіки до офіційної, то можна розрахувати скорегований середній час оплачуваної праці для кожної особи. Цей час буде суттєво більшим від розрахованого для офіційної зайнятості (табл. 2).

Як видно із цієї таблиці, визначений час у середньому за добу для оплачуваної зайнятості в Україні приблизно дорівнює величині цього показника для інших країн. Адже, наприклад, для Канади у 1998 р. величина цього показника для всього населення, яке старше 15 років, дорівнювала 3,6 години [7, с. 173]. Аналогічне значення цього показника і для інших країн (рис. 2).

Для визначення тривалості вільного часу населення нашої країни треба знати, скільки часу в середньому протягом доби українець витрачає на інші види діяльності. Дослідження науковців показали, що в Канаді у 1998 р. особа, яка старша 15 років, витрачає в середньому протягом доби 3,6 год. на неоплачувану роботу, 10,4 год. - на особисті потреби і залишається 5,8 год. вільного часу [7, с. 173]. Такий же приблизно поділ добового фонду часу і для деяких інших країн (рис. 2). 


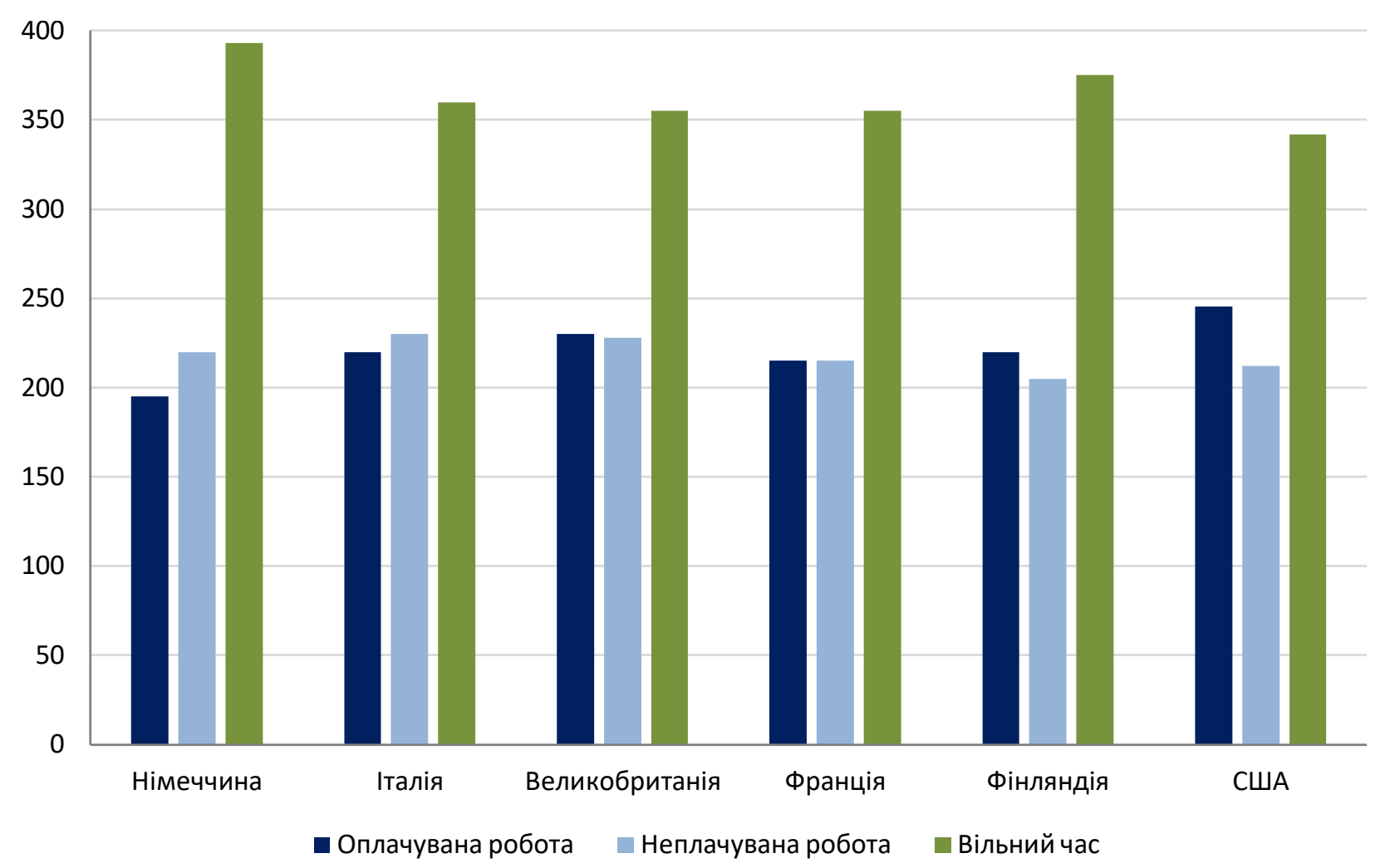

Рис. 2. Домашні роботи, оплачувані роботи і вільний час у 2006 р., хвилин за день на одну особу Дюерело: [8]

Таблиця 2

Середній час за добу, який витрачається на оплачувану працю однісю особою у віці 15-70 років і працездатному віці в Україні у 2010-2017 pp. без урахування та з урахуванням тіньової зайнятості, год.

\begin{tabular}{|l|c|c|c|c|c|c|c|c|}
\hline \multicolumn{1}{|c|}{ Показник $\backslash$ Рік } & $\mathbf{2 0 1 0}$ & $\mathbf{2 0 1 1}$ & $\mathbf{2 0 1 2}$ & $\mathbf{2 0 1 3}$ & $\mathbf{2 0 1 4}$ & $\mathbf{2 0 1 5}$ & $\mathbf{2 0 1 6}$ & $\mathbf{2 0 1 7}$ \\
\hline $\begin{array}{l}\text { Середній час за добу, який витрачається на офіційну опла- } \\
\text { чувану працю однією особою у віці 15-70 років }\end{array}$ & 2,616 & 2,688 & 2,712 & 2,76 & 2,52 & 2,544 & 2,592 & 2,592 \\
\hline Рівень тіньової економіки в Україні, \% до ВВП & 38 & 34 & 34 & 35 & 43 & 40 & 35 & 32 \\
\hline $\begin{array}{l}\text { Середній час за добу, який витрачаєтья на оплачувану } \\
\text { працю однією особою у віці 15-70 років з урахуванням } \\
\text { тіньової зайнятості }\end{array}$ & 3,610 & 3,602 & 3,634 & 3,726 & 3,604 & 3,562 & 3,499 & 3,421 \\
\hline $\begin{array}{l}\text { Середній час за добу, який витрачається на офіційну опла- } \\
\text { чувану працю однією особою працездатного віку }\end{array}$ & 2,952 & 3,024 & 3,048 & 2,928 & 2,88 & 2,904 & 2,952 & 2,952 \\
\hline $\begin{array}{l}\text { Середній час за добу, який витрачається на оплачувану } \\
\text { працю однією особою працездатного віку з урахуванням } \\
\text { тіньової зайнятості }\end{array}$ & 4,074 & 4,052 & 4,084 & 3,953 & 4,118 & 4,066 & 3,985 & 3,897 \\
\hline
\end{tabular}

Джерело: розраховано авторами на основі таблиці 1 i [9]

Оскільки в Україні на оплачувану працю населення витрачає таку ж частку доби, як і в багатьох інших країнах, то напрошується припущення про аналогічні пропорції використання часу доби для інших видів діяльності. За справедливості такого припущення вільний час українця у віці від 15 до 70 років займає від 5,7 год. (23,7\% добового фонду часу) до 6,0 год. ( $25 \%$ часу доби).

Хоча, на нашу думку, робити таке припущення некоректно. Набагато нижчий за економічно розвинуті країни рівень розвитку економіки і неви- сокі порівняно із цими країнами заробітні плати та інші чинники вказують на те, що українці більше порівняно 3 населенням інших країн витрачають часу на домашню роботу i, відповідно, менше відпочивають. Хоча точніше відповісти на вказане питання можуть результати соціологічного обстеження щодо тривалості вільного часу дорослого населення України.

Висновки. Із проведеного дослідження видно, що існують різні підходи до оцінювання рівня економічного добробуту населення. Найчастіше як 
вимірник рівня добробуту використовують валовий внутрішній продукт на душу населення, однак цей показник не враховує проблеми вільного часу. Беззаперечним фактом $€$ залежність добробуту населення будь-якого суспільства від обсягів і якості використання вільного часу його членами. Вільний час - це показник добробуту суспільства, за його величиною можна судити про життєвий рівень населення.
Ефективність використання та розподілу вільного часу визначає продуктивність майбутньої праці людини. Загалом збільшення вільного часу $є$ ознакою зростання добробуту населення. Перспективними напрямами наукових досліджень $є$ проблеми, які пов'язані з використання вільного часу, оцінюванням його тривалості і потребами в ньому кожної особистості та суспільства у цілому.

\section{Список використаних джерел:}

1. Голубник О. Вільний час суспільства як складова економічного добробуту домогосподарств. Формування ринкової економіки в Украӥні. 2019. Вип. 41. С. 119-126.

2. Самуельсон П.А. Макроекономіка. Київ : Основи, 1995. 544 с.

3. Як українці проводять вільний час і чого прагнуть в майбутньому. URL : https://www.nielsen.com/ua/uk/insights/ reports/2015/Spar-time-and-future-for-ukrainians.html (дата звернення: 16.12.2018).

4. Танчин I.3. Соціологія : навчальний посібник. Львів : Укр. акад. друкарства, 2005. 360 с.

5. Бочелюк В.Й., Бочелюк В.В. Дозвіллєзнавство : навчальний посібник. Київ : Центр навчальної літератури, 2006. $208 \mathrm{c}$.

6. Статистичний щорічник України за 2010-2017 роки. URL : www.ukrstat.gov.ua (дата звернення: 20.12.2018).

7. Руководство по подготовке статистических данных об использовании времени для оценки оплачиваемого и неоплачиваемого труда. Нью-Йорк, 2007. URL : https://unstats.un.org/unsd/publication/seriesf/seriesf_93r.pdf (дата звернення: 18.12.2018)

8. Гарин А. Классические вопросы ВВП. URL : http://www.klubok.net/subjects17.html або http://www.klubok.net/ pageid693.html (дата звернення: 01.12.2018).

9. Загальні тенденції тіньової економіки в Україні. Міністерство економічного розвитку і торгівлі України. URL : http://www.me.gov.ua/Documents/List?lang=uk-UA\&id=e384c5a7-6533-4ab6-b56f-50e5243eb15a\&tag=TendentsiiTinovoiE konomiki (дата звернення: 11.12.2018).

\section{References:}

1. Holubnyk O. (2019) Vilnyi chas suspilstva yak skladova ekonomichnoho dobrobutu domohospodarstv [Leisure time of the society as a component of economic welfare of households]. Formation of Market Economy in Ukraine, vol. 41, pp. 119-126.

2. Semiuelson P.A. (1995) Makroekonomika [Macroeconomics]. K. : Osnovy. (in Ukrainian)

3. Yak ukraintsi provodiat vilnyi chas i choho prahnut $\mathrm{v}$ maibutnomu [How Ukrainians spend their free time and what they want in the future]. Available at: https://www.nielsen.com/ua/uk/insights/reports/2015/Spar-time-and-future-for-ukrainians. html (accessed: 16.12.2018)

4. Tanchyn I.Z. (2005) Sotsiolohiia [Sociology]. Lviv : Ukr. akad. drukarstva. (in Ukrainian)

5. Bocheliuk V.Y., Bocheliuk V.V. (2006) Dozvillieznavstvo [Leisure]. Kyiv: Tsentr navchalnoi literatury. (in Ukrainian)

6. Derzhavna sluzhba statystyky Ukrainy (2018) Statystychnyi shchorichnyk Ukrainy za 2010-2017 roky [Statistical Yearbook of Ukraine], Kyiv: Informatsiino-analitychne ahentstvo. Available at: https://www. www.ukrstat.gov.ua (accessed: 20.12.2018).

7. Rukovodstvo po podgotovke statisticheskikh dannykh ob ispol'zovanii vremeni dlya otsenki oplachivaemogo i neoplachivaemogo truda [A guide to the preparation of time use statistics for the evaluation of paid and unpaid work]. N'yuYork, 2007. Available at: https://unstats.un.org/unsd/publication/seriesf/ seriesf 93r.pdf (accessed: 18.12.2018).

8. Garin A. (2011) Klassicheskie voprosy VVP [Classical questions of GDP]. Available at: http://www.klubok.net/ subjects17.html abo http://www.klubok.net/ pageid693.html (accessed: 1.12.2018).

9. Zahalni tendentsii tinovoi ekonomiky v Ukraini [General trends of the shadow economy in Ukraine]. Ministerstvo ekonomichnoho rozvytku i torhivli Ukrainy [Ministry of Economic Development and Trade of Ukraine]. Available at: http://www.me.gov.ua/Documents/List?lang=uk-UA\&id=e384c5a7-6533-4ab6-b56f-50e5243eb15a\&tag=Tendentsii Tinovoi Ekonomiki (accessed: 11.12.2018). 
Pryimak Vasyl, Holubnyk Olha

Ivan Franko National University of Lviv

\section{ASSESSMENT OF LEISURE TIME OF SOCIETY IN THE SYSTEM OF FORMATION OF HOUSEHOLD WELFARE}

With the development of market social and labor relations in Ukraine, the problem of improving the welfare of its population is becoming increasingly important, in particular the issue of increasing and effectively using the free time of its household members. The purpose of the article is to theoretically analyze the nature of leisure time of the population as one of the components of Measure of Economic Welfare of the households of the region or country as a whole and to develop possible approaches to assessing its volume. The basic approaches to the estimation of economic welfare of the population are analyzed. The necessity to consider such a component as leisure time when measuring the economic welfare of a society is substantiated. The directions of leisure use in society are characterized. The structural division of leisure into two parts, namely leisure and "more elevated activity is done". Comparative analysis of paid work, unpaid work and leisure time in different countries is performed. It is established that in Ukraine the value of the indicator "time worked per person for the daily time fund" is much smaller than the value of this indicator for other countries. The difference in the value of the considered indicator for Ukraine and other countries is explained by the large volumes of the shadow economy and the shadow employment in our country. The average time per day spent on paid work by one person between the ages of 15-70 and working age in Ukraine in 2010-2017 without and with shadow employment is calculated. The study shows that the main measure of the level of economic well-being of the population is the gross domestic product (GDP) per capita, but this indicator does not take into account the free time problem. An undeniable fact is the dependence of the well-being of the population of any society on the volume and quality of leisure use by its members. It is known that, in a highly developed economy, the income level is sufficient for a quality rest and an increase in the leisure time of a large part of the population, which is equivalent to an increase in the welfare of the country. Leisure time is an indicator of the well-being of a society, its size can be judged on the standard of living of the population.

Key words: welfare, economic welfare of households, free time, leisure, paid work, unpaid work.

JEL classification: D60, I31, J01, J22. 